\title{
Percolation Fractal Dimension in Scattering Line Shapes of the Random-Field Ising Model
}

F. Ye, M. Matsuda, S. Katano, H. Yoshizawa, D. P. Belanger, E. T. Seppala, J. A. Fernandez-Baca, M. J. Alava

This article was submitted to: International Conference on Magnetism 2003, Roma, Italy 7/21/2003 - 8/1/2003

U.S. Department of Energy

Lawrence Livermore National Laboratory

June 17, 2003 


\section{DISCLAIMER}

This document was prepared as an account of work sponsored by an agency of the United States Government. Neither the United States Government nor the University of California nor any of their employees, makes any warranty, express or implied, or assumes any legal liability or responsibility for the accuracy, completeness, or usefulness of any information, apparatus, product, or process disclosed, or represents that its use would not infringe privately owned rights. Reference herein to any specific commercial product, process, or service by trade name, trademark, manufacturer, or otherwise, does not necessarily constitute or imply its endorsement, recommendation, or favoring by the United States Government or the University of California. The views and opinions of authors expressed herein do not necessarily state or reflect those of the United States Government or the University of California, and shall not be used for advertising or product endorsement purposes.

This is a preprint of a paper intended for publication in a journal or proceedings. Since changes may be made before publication, this preprint is made available with the understanding that it will not be cited or reproduced without the permission of the author.

This work was performed under the auspices of the United States Department of Energy by the University of California, Lawrence Livermore National Laboratory under contract No. W-7405-Eng-48.

This report has been reproduced directly from the best available copy.

Available electronically at http://www.doc.gov/bridge

Available for a processing fee to U.S. Department of Energy

And its contractors in paper from

U.S. Department of Energy

Office of Scientific and Technical Information

P.O. Box 62

Oak Ridge, TN 37831-0062

Telephone: (865) 576-8401

Facsimile: (865) 576-5728

E-mail: reports@adonis.osti.gov

Available for the sale to the public from

U.S. Department of Commerce

National Technical Information Service

5285 Port Royal Road

Springfield, VA 22161

Telephone: (800) 553-6847

Facsimile: (703) 605-6900

E-mail: orders@ntis.fedworld.gov

Online ordering: http://www.ntis.gov/ordering.htm

OR

Lawrence Livermore National Laboratory

Technical Information Department's Digital Library

http://www.llnl.gov/tid/Library.html 


\section{DISCLAIMER}

This document was prepared as an account of work sponsored by an agency of the United States Government. Neither the United States Government nor the University of California nor any of their employees, makes any warranty, express or implied, or assumes any legal liability or responsibility for the accuracy, completeness, or usefulness of any information, apparatus, product, or process disclosed, or represents that its use would not infringe privately owned rights. Reference herein to any specific commercial product, process, or service by trade name, trademark, manufacturer, or otherwise, does not necessarily constitute or imply its endorsement, recommendation, or favoring by the United States Government or the University of California. The views and opinions of authors expressed herein do not necessarily state or reflect those of the United States Government or the University of California, and shall not be used for advertising or product endorsement purposes.

This is a preprint of a paper intended for publication in a journal or proceedings. Since changes may be made before publication, this preprint is made available with the understanding that it will not be cited or reproduced without the permission of the author.

This work was performed under the auspices of the United States Department of Energy by the University of California, Lawrence Livermore National Laboratory under contract No. W-7405-Eng-48.

This report has been reproduced directly from the best available copy.

Available electronically at http://www.doc.gov/bridge

Available for a processing fee to U.S. Department of Energy

And its contractors in paper from

U.S. Department of Energy

Office of Scientific and Technical Information

P.O. Box 62

Oak Ridge, TN 37831-0062

Telephone: (865) 576-8401

Facsimile: (865) 576-5728

E-mail: reports@adonis.osti.gov

Available for the sale to the public from

U.S. Department of Commerce

National Technical Information Service

5285 Port Royal Road

Springfield, VA 22161

Telephone: (800) 553-6847

Facsimile: (703) 605-6900

E-mail: orders@ntis.fedworld.gov

Online ordering: http://www.ntis.gov/ordering.htm

OR

Lawrence Livermore National Laboratory

Technical Information Department's Digital Library

http://www.llnl.gov/tid/Library.html 


\title{
Percolation fractal dimension in scattering line shapes of the random-field Ising model
}

\author{
F. Ye ${ }^{a}$ M. Matsuda ${ }^{b}$ S. Katano ${ }^{b}$ H. Yoshizawa ${ }^{c}$ D. P. Belanger ${ }^{a, *}$ E. T. Seppälä ${ }^{e}$ \\ J. A. Fernandez-Baca ${ }^{d}$ M. J. Alava ${ }^{\mathrm{f}}$ \\ ${ }^{a}$ Department of Physics, University of California, Santa Cruz, CA 95064 USA \\ ${ }^{\mathrm{b}}$ Advanced Science Research Center, Japan Atomic Energy Research Institute, Tokai, Ibaraki 319-1195 Japan \\ ${ }^{\mathrm{c}}$ Neutron Science Lab., Institute for Solid State Physics, Univ. of Tokyo, Shirakata 106-1, Tokai, Ibaraki $319-1106$ Japan \\ ${ }^{\mathrm{d}}$ Condensed Matter Sciences Div., Oak Ridge National Laboratory, Oak Ridge, Tennessee 37831 USA \\ ${ }^{\mathrm{e}}$ Lawrence Livermore National Laboratory, L-415, Livermore, CA 94551 USA \\ ${ }^{\mathrm{f}}$ Dipartimento di Fisica, Università "La Sapienza", P. le A. Moro 2, 00185 Roma, Italy
}

\begin{abstract}
Neutron scattering and simulation line shape data show evidence for fractal structure from spanning clusters in the $d=2$ and $d=3$ random-field Ising models as realized in dilute antiferromagnets.
\end{abstract}

Key words: Random-field Ising model, neutron scattering, percolation

PACS: 75.50.Lk, 61.12.-q, 64.60.Ak

Rigorous proofs of the two (2D) and three dimensional (3D) random-field Ising model (RFIM) indicate that there is a phase transition in $3 \mathrm{D}$, but not in 2D [1]. However, recent simulations show that in both dimensions there is a percolation type of order: in 2D at low random-field values and in $3 \mathrm{D}$ just above the phase transition [2]. The importance of the percolation phenomenon is not only of pure theoretical interest, but it may also have implications in the interpretation of experimental results such as line shapes from the neutron scattering experiments due to the fractal character of the spanning cluster. This can be tested in the simula-

\footnotetext{
* Corresponding author, Tel: +1 831459 2871; Fax: +1 8314593043

Email address: dave@dave.ucsc.edu (D. P. Belanger).
}

tions as well, where the Fourier transform of spinspin correlation functions, representing the structure factor $S(q)$, shows scaling with the percolation fractal dimension $D_{f}=91 / 48$ (see Fig. 1). In the figure $S(q)$ is calculated from ground states of $2 \mathrm{D}$ RFIM with diluted antiferromagnet type of disorder, where the magnetic dilution is $1-x=0.30$, and square-lattices. The ground states are found using an exact optimization algorithm.

Experimental scattering intensity line shapes are given by $S(q)$ folded with instrumental resolution. One expects $S(q)$ for $T>T_{c}$ to be governed by a scaling function which can be approximated by [3]

$f=A \kappa^{\eta-2}\left(1+\phi^{2} q^{2} / \kappa^{2}\right)^{\eta / 2} /\left(1+\psi^{2} q^{2} / \kappa^{2}\right)$

where $\psi=1+\frac{1}{2} \eta \phi^{2}$ and $\kappa$ is the inverse fluctuation 


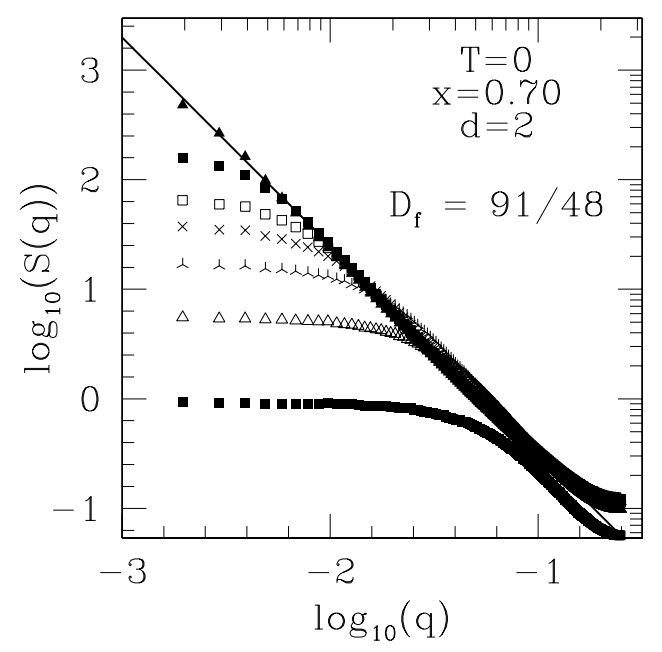

Fig. 1. Simulation results for $\log _{10}(S(q))$ vs. $\log _{10}|q|$ for $d=2$. The solid line is $q^{-91 / 48}$. Data sets, highest to lowest, are for $H / J=0.50,0.75,1.00,1.25,1.75,2.50$, and 3.25 , respectively.

correlation length. In the mean-field approximation (MF), $\eta=0$, yielding a simple Lorentzian. For $H=0$, theory and experiment show that $S(q) \approx$ $f$ with $\eta$ very small. However, the RFIM result in MF is $S(q)=f+R(H) f^{2}$ with $\eta=0$.

Experimental RFIM data for $H=10 \mathrm{~T}$ in $\mathrm{Fe}_{0.85} \mathrm{Zn}_{0.15} \mathrm{~F}_{2}$ were obtained at $13.7 \mathrm{meV}$ using the JAERI TAS-2 neutron spectrometer with pyrolytic graphite (PG) monochromator and analyzer (002) reflections and a PG filter. Half-widthat-half-maximum resolutions were $0.0019,0.0084$ and 0.052 reciprocal lattice units in the transverse, longitudinal and vertical directions, respectively.

Using techniques developed previously [3], fits to $S(q)=f+R(H) f^{2}$ for $t<4.5 \times 10^{-2}$ and $4 \times 10^{-3}<|q|<3 \times 10^{-1}$ yield $\eta=0.58 \pm 0.05$ and $\nu=1.18 \pm 0.05$, but do not seem to yield convergence to a universal scaling function $f$ as $H$ is increased, as one might have expected. Motivated by the simulations described above, fits to $S(q)=$ $f$ for $t<6 \times 10^{-2}$ and $2 \times 10^{-3}<|q|<1.5 \times 10^{-1}$ were made for $T>T_{c}=63.6 \mathrm{~K}$, and $H=10 \mathrm{~T}$, as shown in Fig. 2, giving exponents $\eta=-0.5 \pm 0.05$ and $\nu=1.20 \pm 0.05$. As $t=\left(T-T_{c}\right) / T_{c} \rightarrow 0$, the line shapes follow the fractal line shape $S(q) \rightarrow$ $|q|^{-D_{f}}$, shown folded with the instrumental resolution by the solid curve in Fig. 2, where $D_{f}=$

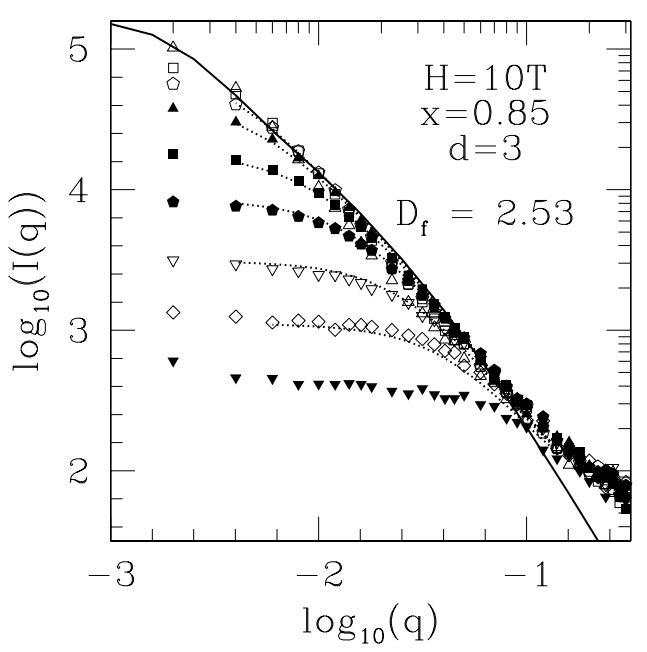

Fig. 2. Scattering results for $\log _{10}(I(q))$ vs. $\log _{10}|q|$ for $d=3$ in $F e_{0.85} Z n_{0.15} F_{2}$ at $t=3.9 \times 10^{-4}, 3.5 \times 10^{-3}$, $5.1 \times 10^{-3}, 7.5 \times 10^{-3}, 1.2 \times 10^{-2}, 1.8 \times 10^{-2}, 3.1 \times 10^{-2}$, $5.0 \times 10^{-2}$, and $1.0 \times 10^{-1}$ (lowest set). The solid curve is $q^{-2.53}$, folded with instrumental resolution. The dotted curves are fits to Eq. (1).

$2-\eta=2.53$ for $d=3$. This suggests that $S(q)$ is strongly influenced by the fractal character of the spanning clusters, as simulations suggest. For $H>$ 0 and $T<T_{c}$, and for $H=0$, no RFIM spanning clusters are expected to exist and experimental line shapes in these cases are not fractal powers of $q$.

Work was partly supported by DOE Grant No. DE-FG03-87ER45324, partly performed under the auspices of the U.S. Dept. of Energy at the University of California/Lawrence Livermore National Laboratory under contract no. W-7405-Eng-48, partly supported by a Grant-in-Aid for Scientific Research from MONKASHO, Japan, by the USJapan Cooperative Neutron Scattering Program, and partly sponsored by the US DOE under contract DE-AC05-00OR22725 with ORNL, managed by UT-Battelle, LLC.

\section{References}

[1] J. Bricmont and A. Kupiainen, Phys. Rev. Lett. 59 (1987) 1829; M. Aizenman and J. Wehr, Phys. Rev. Lett. 62 (1989) 2503.

[2] E.T. Seppälä and M.J. Alava, Phys. Rev. E 63 (2001) 066109; E.T. Seppälä, A. M. Pulkkinen and M. J. Alava, Phys. Rev. B 66 (2002) 144403. 
[3] Z. Slanič, D.P. Belanger and J.A. Fernandez-Baca, Phys. Rev. Lett. 82 (1999) 426. 